\title{
Local Energy Efficiency Policy
} Implementation in China: Bridging the Gap between National Priorities and Local Interests*

\author{
Genia Kostka ${ }^{\dagger}$ and William Hobbs
}

\begin{abstract}
This paper analyses Chinese sub-national governments' implementation strategies to meet national energy efficiency targets in the 11th Five-Year Plan (2006-2010). Previous research has focused on the ways governance practices and decision-making structures shape implementation outcomes, yet very little attention has been given to what strategies local leaders actually employ to bridge national priorities with local interests. To illustrate how local leaders work politically, this paper highlights specific implementation methods officials use to strengthen formal incentives and create effective informal incentives to comply with energy efficiency mandates. The analysis is drawn from 53 interviews conducted in June and July of 2010 in Shanxi, a major coal-producing and energy-intensive province. Findings suggest that local government leaders conform to national directives by "bundling" the energy efficiency policy with policies of more pressing local importance or by "bundling" their energy efficiency objectives with the interests of groups with significant political influence. Ultimately, sub-national government officials frame policies in ways that give them legitimacy at the local level.
\end{abstract}

Keywords: policy implementation; central-local relations; energy; informal incentives; climate change; China

\section{Introduction}

Secure energy resources and their intelligent use are keys to China's continued, rapid development. The country recently overtook the United States as the world's largest energy consumer, according to an International Energy Agency

* The authors are grateful for funding from the Developmental Leadership Program (DLP). The authors also wish to thank Shi Xiangying, Adrian Leftwich, Tom Harrison, Christine Polzin, Sarah Eaton and Kyoung Shin for helpful feedback on earlier drafts of this paper.

$\dagger$ Frankfurt School of Finance and Management. Email: geniakostka@gmail.com (Corresponding author)

* University of California, San Diego, Email: whobbs@ucsd.edu. 
(IEA) estimate ${ }^{1}$ and, as China's citizens become wealthier, concerns about their increasing consumption capability and the consequent production and energy consumption growth will continue into the coming decades. This energy consumption growth has wide implications for the air pollution, greenhouse gas (GHG) emissions, and energy scarcity crises facing China and the world. The prioritization of issues by the international community and China may vary as there is much more emphasis on climate change and pollution outside of China, while concerns about economic growth and energy security take precedence domestically, but China's energy policy will increasingly find itself on the top of national and international policy agendas. China has begun to address energy consumption growth concerns through its 11 th Five-Year Plan energy intensity ${ }^{2}$ reduction targets, including introducing the self-imposed national target of a 20 per cent reduction in energy intensity against 2005 levels by 2010. However, at the subnational levels, socioeconomic and political benefits from decreased local energy consumption and decreased emissions are not foregone conclusions and energy efficiency may receive less priority despite this national emphasis. While sustained economic growth based on continued availability of energy resources and environmental pollution problems are important issues for the country as a whole, local governments may be more willing and able to manage short-term, local problems such as enterprise cash flow difficulties, attracting foreign and domestic investment, and social stability concerns. These problems are more self-contained and manageable, with clearer and more direct local benefits, than issues that require significant collective action like energy policy implementation.

This paper thus examines the means through which local governments implement energy efficiency policy. The main hypothesis is that local governments seek to implement national administrative directives by combining the energy consumption management policy with policies of greater or more pressing importance for the local government, a tactic which we term "policy-bundling," or by linking their energy efficiency objectives with the immediate interests of different actors to improve the implementation of one or more policies, which we term "interest-bundling." Officials often opt to "kill two (or more) birds with one stone" by choosing implementation pathways that balance local priorities with national targets and are more likely to faithfully implement energy conservation policies and projects which also address salient business, economic, safety, pollution, and political legitimacy interests and concerns in their local constituencies. Local governments are less likely to strictly implement energy conservation policies that lack "bundling" potential and will employ foot-dragging measures such as seeking loopholes in the implementation guidelines.

Shanxi province was chosen as the research region as it is well-known for its coal production and large proportion of energy-intensive enterprises. Both enterprise sizes and ownership structures vary across Shanxi, with more state

2 Energy intensity is the energy consumption per unit GDP. 
ownership and larger enterprises in the north and more private ownership and smaller enterprises in the south. The scale of industrial production and energy consumption in Shanxi make energy savings and emissions reduction (ESER) policy especially pressing and relevant for the province. Nevertheless, the lack of a diversified industrial structure and decreased employment opportunities make implementation of ESER policy difficult, especially given that Shanxi has fewer opportunities than other regions in China such as coastal regions or areas most benefited by the "Open Up the West" policies.

In the 11th Five-Year Plan, Shanxi was assigned an energy intensity reduction goal of 25 per cent by 2010 compared to the 2005 level, which is higher than the national target of 20 per cent. Figures provided in recent Shanxi Provincial Economic Commission reports show the province as being on track to meet or surpass its 11th Five-Year Plan energy intensity targets. ${ }^{3}$ However, the specifics of this successful implementation have not been studied, and this research shows that local officials' interests and incentives have been key to these policy outcomes.

The analysis is drawn from 53 interviews conducted in the provincial capital, five municipalities, and eleven counties during June and July 2010. The majority of interviewees were officials from Economic Commissions, Environmental Protection Bureaus, Development and Reform Commissions, and Construction Bureaus, as well as industrial enterprise managers involved in energy intensity reduction and efficiency programs. Interviews were semi-structured and provided an understanding of overall implementation at the provincial, municipal, and county levels through the study of local circumstances, along with insight into the similarities and variations in implementation among localities. The analysis also draws from government policy documents and reports, ESER statistics, statistical yearbook data, and internal enterprise energy consumption statistics.

The next section introduces concepts and arguments relevant to understanding the implementation of national ESER policies at the local level. The subsequent discussion provides an overview of national energy efficiency efforts since 2006 and describes the local policy context in Shanxi province. The paper then analyses local players and interests in the implementation of two industrial energy efficiency policies: the Shanxi Top-1000 Enterprise Program and the policy of "elimination of backward production capacity" and small plant closure. The research concludes by highlighting the politics of bundling as a common implementation tactic at the local level and offering a brief discussion of the implications of the findings.

\section{Energy Efficiency Policy Implementation: Bundling and Framing}

China's energy efficiency programs at the national level have received a great deal of attention in the public policy literature, ${ }^{4}$ yet an analysis of local 
implementation is essential for a full understanding of the national ESER initiative. Most China observers are well aware of gaps between the central government's official national policies and their practical outcomes at local levels. ${ }^{5}$ Often, a conflict exists between government levels because national policies at times fail to take into account policies' potential negative impacts on local businesses, employment, and taxation revenues. National policies without sufficient local support and legitimacy are only implemented strictly when there is direct and constant attention from the center. Policy implementation outcomes therefore often directly or indirectly relate to the differences between priorities at the national level and local incentives.

Existing approaches focus on the ways governance practices and decisionmaking structures shape implementation outcomes, yet very little research has shown what strategies local leaders actually employ to bridge national priorities with local interests. For energy efficiency policy implementation, the clearly defined energy intensity reduction targets, the strict punishments through denial of promotion and formal censure for government officials and enterprise managers if they fail to meet them, and the high cost and at times redistributive nature of energy efficiency improvements make ESER policy implementation a site of political contestation. ${ }^{6}$ Specifically, percentage targets are rigid and ranged from 12 per cent up to 30 per cent against 2005 levels. In order to meet targets, officials from the Economic Commission negotiate with local enterprises to convince managers to improve energy efficiency, whether or not such investments are cost-efficient within a practical time horizon. At the same time, local implementers reorganize industrial structures by consolidating production capacity at the most efficient enterprises or by reducing the share of energy-intensive production in their constituencies through, for instance, promoting industries in the service sector such as tourism.

To illustrate how leaders work politically, this paper highlights specific implementation tactics that officials use to bring enterprises and the public on board in support of their own professional objectives. The first practice is interestbundling, whereby government officials link their own political interests with the economic and political interests of the large enterprises essential to both successful implementation of the ESER policy and local economic growth. Officials align their interests with those of state-owned enterprise (SOE) and large private enterprise managers by communicating the importance of the ESER policy and indicating the willingness of the local government to provide compensatory benefits, such as assurance of uninterrupted business operation and preferential access to land and funds for enterprises who comply. The specific incentivization process is often flexible, open to negotiation, and depends on an exchange of

5 For a discussion on the "environmental implementation gap" in China's highly decentralized and fragmented governing structure, see Lieberthal and Oksenberg 1988; Economy 2004; van Rooij 2006; Kostka and Hobbs forthcoming; Ran 2009.

6 For an in-depth description of the ambiguity-conflict model of implementation, see Matland 1995. 
benefits outside of the formal incentive structure. It hinges on the provision, explicit or implicit, of compensatory benefits, and is dependent upon the level of enticement, appeasement, or pressure needed to make enterprises' incentives to improve energy efficiency on par with those of the implementing officials who will be rewarded or promoted for the enterprise achievements. Officials also take competing interests such as economic growth and employment into consideration during implementation, as such factors also affect government officials' evaluations. This interest-bundling approach turns energy efficiency policy implementation into a somewhat cooperative venture and avoids adversarial relationships with important local enterprises. This interest "bundling" is somewhat comparable to "logrolling" in American politics, which occurs when legislators trade votes in exchange for cooperation on other issues. ${ }^{7}$ The main difference between interest-bundling and logrolling is that bundling occurs most often in policy implementation rather than during policy formulation. For energy efficiency bundling, local officials and enterprises cooperate on energy efficiency in exchange for compensatory benefits for the enterprises on other issues.

The second implementation practice is policy bundling. Some ESER policies are implemented as parts of larger campaigns, and connected with policies and concerns of more local or immediate interest like local pollution control or work supervision and safety. At other times, their implementation may be implicitly tied to formally unrelated policies with greater public emphasis and stronger official support. These approaches increase public support and lessen resistance to implementation. The third tool is framing, a concept that originates from sociological research. ${ }^{8}$ Linguistic reframing of policies allows officials to shape public perceptions. ${ }^{9}$ In this study, research suggests that local leaders frame by conceptualizing and describing energy efficiency policies in ways that play to interests in their localities. This helps to create coalitions to support implementation of initiatives which are prima facie detrimental to interest groups or the public in general. Through these methods, municipal and county officials with unambiguous incentives to meet energy intensity target reductions can balance national and provincial demands with local interests. At the same time, they bundle ESER policy in ways that make it relevant to concerns of greater local importance. Ultimately, local officials frame policies and programs of national and international concern in ways that give them legitimacy at the local level.

In the following two sections, this paper introduces national and provinciallevel energy efficiency efforts, highlighting the formal policy structures. This description also points out the shortfalls of formal incentives that necessitate policy implementation manoeuvres outside of these structures. The paper then 
continues with a detailed analysis of the corresponding local implementation manoeuvres and outcomes.

\section{National Context: Energy Efficiency Efforts}

Between 2002 and 2005, China's energy intensity increased at an average of 3.8 per cent ${ }^{10}$ reversing a long-term trend of continuous energy efficiency improvements. In response to this development, the central government in 2004 began to introduce a series of policies, administrative plans, and laws to fill this gap and strengthen energy conservation work. Most importantly, in 2006, the Chinese central government introduced an ESER program, which relies on administrative measures and tools deployed in China's fragmented vertical and horizontal (tiao tiao kuai kuai 条条块块) governance structure, the most important of which are mandatory, "hard" (ying xing 硬性) energy intensity reduction targets for government departments and enterprises. Other administrative measures and tools introduced between 2006 and 2008 are less stringent, but also important. In concert with the introduction of the hard targets, the central government also published a list of ten key energy-savings projects, ten key "people's projects," energy efficiency guidelines and industry efficiency standards, along with other government documents to guide government and enterprise implementation of the energy efficiency policy.

As noted in the literature, hard targets in the cadre responsibility system are generally reserved for economic growth goals and measurements of social stability. ${ }^{11}$ Energy policies of the 11th Five-Year Plan and the new developments in cadre management thus reflect the great emphasis placed on energy saving by the highest levels of the Chinese Communist Party (CCP) and State Council, and can be considered a national reassessment of the "growth at any cost" model previously pursued throughout the country. Yet, the ultimate success or failure of national initiatives continues to depend on local implementation.

Beijing made it clear that faithful implementation of energy efficiency goals are a national priority, but the ESER program, begun in 2006 and in earnest at the provincial level in 2007, had a difficult start. Early government reports indicated that most provinces fell far short of initial yearly energy intensity reduction targets, even in provinces with five-year targets of 12 to 18 per cent, much less those with targets of up to 25 per cent. ${ }^{12}$ By the end of 2008 , the country seemed on track to meet its energy intensity reduction target of 20 per cent, but, in winter 2009, this trend reversed and energy intensity in China increased by 3.2 per cent, ${ }^{13}$ bringing into question the nation's ability to meet its goals. In May 2010, Chinese Premier Wen Jiabao called for local officials to use an "iron 
hand" (tie de shouwan 铁的手腕) when implementing the ESER policy, pushing the nation to ensure completion of its ESER targets stated in the 11th Five-Year Plan. ${ }^{14}$

\section{Local Context: Energy Efficiency Policy in Shanxi Province}

Shanxi province has a high proportion of energy-intensive industry. In 2008, overall industrial production accounted for 54 per cent of GDP and heavy industry accounted for 81 per cent of provincial final energy consumption. ${ }^{15}$ This carries with it implementation and transitional challenges, yet Shanxi has nonetheless arguably successfully implemented ESER policy. The heads of the Shanxi Economic Commission and Shanxi Development and Reform Commission have formulated policies stricter than national requirements, and the province is on track to meet its ESER goals. The success in meeting its energy intensity reduction target is partly due to its preexisting industrial structure. For example, heavy industries have more potential for energy savings, and large industrial plants, prevalent in northern Shanxi and lacking in some other provinces, have scale advantages as some upgrades are impossible for smaller plants. However, progress can be also attributed to the unprecedented provincial emphasis in the past five years.

Provincial practices overall heavily reflect policies at the national level. The Shanxi People's Government passed on the 11th Five-Year Plan's provincial 2010 goal, of a 25 per cent reduction in energy intensity against 2005 levels, to lower level governments and departments. The 2007 decision by the State Council to turn energy intensity reduction into "hard targets" was outlined in provincial policy in 2008. The provincial government also distributed its nationally assigned goal of completing 4.6 million square meters of energy-saving building renovations to lower level governments and departments, along with energy-efficient light bulb dissemination, district heating and other targets. ${ }^{16}$

Yet, provincial policy is not limited to national requirements. Shanxi leaders, including the governor and heads of the Shanxi Economic Commission and the Shanxi Development and Reform Commission, will be held responsible for progress in energy efficiency by the end of the 11th Five-Year Plan and therefore have strong incentives to ensure completion of national efficiency requirements when formulating Shanxi's provincial policy. Provincial leaders went beyond national requirements and made provincial ESER policy stricter than national policy to ensure their completion, as leaders anticipated some local ESER efforts would fail or would be discounted by national inspection teams. Provincial targets assigned by the national government were raised for municipalities, counties, and enterprises to ensure completion of the overall provincial 11th Five-Year 
Plan target. In one municipality, for example, targets at the county level generally ranged from 27 per cent to 30 per cent in energy intensity reduction. ${ }^{17}$ The inflation of targets at the lower levels is a common practice in Chinese policy campaigns. In supplement to national policies, Shanxi province introduced a Top-200 Enterprise Program modeled after the national Top-1000 Enterprise Program, ${ }^{18}$ which requires the most energy-consuming enterprises to sign energy intensity reduction contracts with the provincial government. This provincial program was later expanded to a provincial 1000 Enterprise Program after improved energy-use calculations. These national and provincial top-enterprise programs were intended to improve energy efficiency at the nation's and province's largest energy-consuming enterprises. The Economic Commission also approved provincial energy efficiency standards more stringent than national standards in some industries such as steel and magnesium. ${ }^{19}$

These ambitious targets and policies created a provincial energy efficiency policy structure strongly in line with national interest, yet created implementation difficulties, especially regarding funding. Given the expansion of energy efficiency programs, Shanxi province uses its own provincial funds to finance local energy efficiency projects. In particular, in 2007 the Shanxi People's Government created a "Coal Sustainable Development Fund" through taxation of all provincial coal exports and since then has used part of this money to provide funding for energy-saving initiatives, in addition to projects to counteract the detrimental impacts of coal extraction in the province..$^{20}$ The establishment of this fund took advantage of provincial interest and circumstance and bundled them with both coal mining concerns and the ESER implementation incentives.

This Coal Sustainable Development Fund raises the price of exported Shanxi coal, yet serves a number of purposes. First, it aims to soften the social and economic consequences of coal mining in Shanxi. Second, the tax and its use ensures that other provinces benefiting from the use of Shanxi coal foot the bill for costs not reflected in the price of coal. Third, it aims to raise the costs of exports and keep Shanxi resources within the province to ensure greater GDP creation from industrial processing, instead of low-wealth creation from exporting natural resources. Fourth, and most importantly, it fills government coffers and greatly enhances provincial policy implementation capacity in a number of key areas, including city greening initiatives and ESER policy implementation. Between March 2007 and the end of 2009, the fund reportedly collected over 43 billion yuan. ${ }^{21}$

In addition, an alignment of interests was not limited to financial capacity building, but also occurred during the formulation of the relatively stringent industry efficiency standards. As mentioned above, Shanxi province enacted

17 Interview 21, July 2010, municipal Economic Commission official.

18 For an overview of the national program, see Price, Wang and Jiang 2010.

19 Interview 51, July 2010, provincial Economic Commission official.

20 Shanxi People's Government Document No. 32 (September 2007).

21 Guo 2010. 
provincial energy efficiency standards in industries such as steel and magnesium stricter than those set out at the national level. These provincial efficiency standards are created by the enterprises themselves giving them room to account for their own interests. Although it seems counter-intuitive for enterprises to willingly draft tough standards, especially when they are sufficiently stringent to lead to cost increases, in fact, many large enterprises have incentives to create high efficiency standards to squeeze small producers out of the industry and increase their market share. One manager of a large magnesium enterprise, for example, cited this as a major reason for supporting strict standards. ${ }^{22}$ Indeed, this enterprise pushed for standards approved in Shanxi to also be approved at the national level, but met with resistance from enterprise owners in other provinces and from national government officials concerned that they would limit growth in the industry.

However, despite these funding and standard-setting factors some provincial policies continued to run against local economic business interests. Many energy efficiency methods promoted by the national and provincial governments provided few enterprise cost-savings, except in the very long term. This is especially the case as compensation and subsidies continue to be insufficient. For example, subsidies and rewards distributed by the provincial Development and Reform Commission and sometimes by the municipal and county governments are considered "symbolic" and are not always given out in a consistent manner. When subsidies are provided, they are given after the project completion, creating a high level of uncertainty for enterprises considering energy-saving projects. According to one municipal official, between 2007 and 2009 there were around 250 industrial projects to upgrade production efficiency in the municipality. Of these, only 44 of the largest projects received subsidies that on average covered between 20 and 30 per cent of the initial investment costs. ${ }^{23}$ Indeed, throughout Shanxi, only economically and politically significant enterprises with very large production capacity and relatively advanced production capability consistently receive compensation, subsidies and rewards. As an indication of their scale, these large plants usually employ several thousand workers.

Due to insufficient financial resources and policy aspects that ran in opposition to local interests, the necessity for local officials to bundle provincial and national interests with local interests remained. Among different ESER programs and measures the most important and locally emphasized were the provincial Top-1000 Enterprise Program, the "elimination of backward production capacity" and small plant closure policy, industry energy efficiency standards, and social "ten key projects" program such as efficient light bulb programs, district heating and waste-water management, and energy-saving renovations in residential housing. This paper will examine two of them - the Shanxi Top-1000 Enterprise Program and the "elimination of backward production 
capacity" and small plant closure policy - and analyse the extent to which bundling of interests and policies, along with framing strategies for the interests and concerns existent in localities, were used to address the challenges to implementing ESER policy.

\section{Local Implementation: Interest-Bundling, Policy-Bundling, and Framing}

\section{Shanxi Top-1000 Enterprise Program}

The Top-1000 Enterprise Program in Shanxi is perhaps the most important component of the ESER policy at the local level. Enterprises on the list account for 90 per cent of energy use in the province, according to calculations by the Shanxi Provincial Economic Commission, ${ }^{24}$ and energy efficiency improvements at these enterprises are the primary factor determining officials' progress towards energy intensity reduction hard targets. To implement the 1000 enterprise program, local People's Government officials sign responsibility contracts with the higher level government committing themselves to energy intensity reductions in their jurisdictions, and then sign responsibility contracts with the enterprise managers on the 1000 enterprise list, committing them to specific energy consumption targets.

Because the targets in the cadre responsibility system are tied to these agreements, local leaders and officials have strong incentives to implement the Top-1000 Enterprise policy. At the same time, however, they have limited willingness and capacity to enforce targets and standards. Local county and municipal leaders such as mayors and party secretaries have greater influence and implementation capacity than Economic Commission officials, but are not always willing to give priority to the enforcement of ESER policy. Mayors and party secretaries have many, sometimes conflicting, priorities and targets, and energy intensity targets are just one of them. As a result, Economic Commission officials often carry out ESER policies without the mayor's or party secretary's unconditional support for strict enforcement measures and must consider economic and political interests of enterprises to ensure their cooperation.

In terms of supervision and enforcement capacity at the county level, usually only one or two people in the Economic Commission are in charge of energy efficiency at enterprises. The same officials are responsible for many different industrial production and technology standards. With limited industry knowledge, it is difficult for them to thoroughly evaluate the required energy reports delivered by the enterprises. Even with greater human resources and skills, local Economic Commission officials cannot effectively implement ESER policy without the support and cooperation of large energy-intensive enterprises, such as iron and steel,

24 Shanxi sheng jingji he xinxihua weiyuanhui 2010. This statistic was calculated using a broad definition of the word "industrial." The provincial Development and Reform Commission and the provincial Construction Bureau went by different numbers. An official from the Construction Bureau, for example, believed the number should be closer to one third, with transportation and housing taking up the remaining two thirds (Interview 27, July 2010, provincial Construction Bureau official). 
non-ferrous metals and coking enterprises. The local governments can punish enterprises which exceed industry efficiency standards by raising such enterprises' electricity costs and ordering utility companies to cut off electricity and water, a policy commonly referred to as "cut water cut electricity" (duanshui duandian 断 水断电), but the legal basis for these punishments is tenuous, and enterprises can resist or appeal their enforcement.

Given their limited willingness and ability to enforce the policy, local leaders and officials often choose to bundle their own political interests with the economic and political interests of enterprise managers. Government officials ensure and explain to managers the formal rules and incentives within the national and provincial ESER policy such as provincial, and in some cases municipal, subsidies and often also provide informal incentives and benefits outside the formal implementation structure. Although the existence of subsidies and formal incentives such as promotions are clear, subsidy and compensation applications are complex and mistakes will result in denial of funding. Also, subsidies are limited and enterprise managers may be doubtful that their applications will succeed. Assurances and assistance from local officials can thus be essential to an enterprise manager's confidence that ESER measures will receive compensation from the government. On the informal side, when local officials and managers have close relationships, personal or professional, they persuade enterprises of benefits through unofficial means, such as personal appeals, preferential treatment, and compensatory benefits for enterprises that make voluntary efforts to reduce energy consumption. Managers of large and profitable enterprises with strong party connections and the capacity to upgrade production improved energy efficiency without the assurance of monetary compensation. For example, one enterprise improved energy efficiency and only later received compensation for each ton of saved energy after the adoption of a new national policy. ${ }^{25}$ Highlighting potential political, economic, or social benefits to be gained from implementing ESER measures is one of the informal means employed by government officials. Thus, government officials bundle their own political interests such as evaluations and promotion opportunities with the economic and political interests of enterprise managers, which vary according to enterprise forms of ownership.

Formal and informal incentives and benefits differ for SOEs and private enterprises. For SOEs, managers are more easily incentivized to meet ESER targets as they can be punished through political performance evaluations if they fall short of their goals. They can be excluded from year-end bonuses and be subject to other political punishments. ${ }^{26}$ Beyond this, SOE managers may also implement the policies for perceived political benefit outside of the formal incentive structure. For some large SOE managers, the importance placed on energy efficiency communicates an advancement opportunity. If they can significantly increase 
energy efficiency and increase GDP per unit of energy consumed, they may be able to expect a number of political benefits and perhaps a promotion. For example, it is common knowledge among Shanxi enterprise managers that the former head of the largest iron and steel plant in Shanxi, Taiyuan Iron and Steel (Taigang 太钢), was promoted to deputy governor of the province after increasing efficiency and raising production standards at the company. In general, political benefits such as promotions into prestigious government jobs are the greatest incentives for officials and SOE managers as opposed to monetary compensation incentives such as continued eligibility for year-end bonuses.

Political incentives, on the other hand, are not strong motivators for private enterprise owners and instead compensatory benefits or other implicit exchanges are offered to increase enterprises' energy efficiency efforts. Private enterprises primarily evaluated ESER policies based on profit-maximization criteria and energy efficiency projects do not always result in significant cost-savings. Accordingly, local officials often have to use signaling (observable indications of policy preferences ${ }^{27}$ ) and persuasion to assure business managers of economic benefits, which might include secure long-term operation, preferential treatment for future expansion projects, and increased market share resulting from eventual consolidation of production capacity to the most efficient enterprises. A key component of the secure long-term operation incentive is continued access to local financing. Local banks, although officially making decisions independently, commonly align loan decisions with interests of local mayors and party secretaries. ${ }^{28}$ Loans are thus tied to the loan preferences of local leaders, who are incentivized to prioritize large, energy-efficient enterprises that met their ESER targets. Therefore, for private enterprise, ESER interest-bundling is to some extent a race to stay on the government's good side and maintain preferential access to government-provided resources. This rent-seeking behaviour induced by interestbundling is a major component of progress in energy efficiency implementation.

Informal assurances and actual political and economic incentives are sometimes not enough to convince enterprise managers to improve energy efficiency. Some cases, especially in the final year of the 11th Five-Year Plan, require the "iron hand" advocated by Premier Wen Jiabao. Officials thus sometimes seek compromises to ensure enterprise managers will be as receptive as possible to enforcement. One way that local governments can bundle their ESER "hard target" interests while also preventing long-term, undue harm to local interests is to use a measure called "sleeping management" (xiumian guanli 休眠管理). For example, by early 2010 local leaders in one county realized that they were not able to meet their ESER targets set in the 11th Five-Year Plan because of a single new coal power plant, which had greatly increased the overall energy intensity in the county. The income from this new plant was important to the local economy and government revenue, yet the detrimental impact on the energy intensity in the

28 Interview 16, July 2010, manager of private industrial enterprise. 
locality was undeniable. As a compromise, the local government therefore required this enterprise and other energy-intensive enterprises which had greatly exceeded energy consumption standards to close in rotation for several months at the end of 2010. In this way, the local leaders hoped to satisfy their ESER targets without actually having to close any of the concerned enterprises completely and suffer the social and economic consequences that would result.

When bundling is not effective, officials resort to more coercive means. Although local governments rarely resort to harsh punishments, they still use them as very real threats for enterprises if the jurisdiction is close to falling short of the officials' ESER targets and the mayor and other high level officials find themselves with their "backs to the wall." Given tight personal networks between government officials and larger enterprise managers, local enterprises are aware of the importance of energy reduction to mayors and high level officials, even if they have little reason, legally or with respect to political influence, to listen to the appeals of Economic Commission representatives. Signaling by the government, often through informal channels such as former government officials in management positions at large private enterprises, makes it clear to private enterprises that if they do not comply with ESER policies they will certainly be punished. For large enterprises which reduce energy consumption, the signaling from the government officials also assures them that when they increase costs in the short term they will not be undercut by other enterprises who avoid energy-saving renovations. In this way, they can anticipate that if noncompliant enterprises cut corners to take away market share, they will be punished or even closed. Noncompliant enterprises are often closed relatively late; despite this, the preemptive bundling of energy efficiency policy with formally unrelated incentives provides the benefits for enterprises to implement upgrades early.

\section{Policy of "elimination of backward production capacity" and small plant closure}

The second major and perhaps most reported ESER effort in Shanxi is the push to close inefficient and energy-intensive production lines and small industrial enterprises. To implement it, the Economic Commission in a county or municipality identifies enterprises that violate national and provincial guidelines on industrial equipment and production scale standards. After receiving the approval of the mayor, local Economic Commissions publish lists of enterprises or production lines that do not meet energy efficiency requirements and list time frames for "voluntary" closure. Some closed enterprises or enterprises that shut down outdated production equipment receive compensation of around 20 to 30 per cent of the closed enterprise or production line value, but the majority of such enterprises do not. ${ }^{29}$ Although the definition varies across sectors, a small enterprise in China generally has fewer than 2000 employees and less than 300

29 Interview 28, July 2010, municipal Economic Commission official; Interview 13, July 2010, county Development and Reform Commission official. 
million yuan in sales. ${ }^{30}$ However, the small enterprises discussed in this section have at most several hundred employees and the closed plants, of which many are satellites of larger enterprises, often employ from 30 to 100 workers. Those enterprises and plants which were closed were often too small in terms of production scale or without financial capability to upgrade. When implementing the plant and production-line closure policy, local governments are more likely to resort to differentiated electricity pricing and cutting off electricity and water, especially for small enterprises. In some cases, local mayors can ask the Security Bureau to send police officers to assist with forced closures, along with the removal and destruction of factory equipment. One case in which strict forms of enforcement were used prior to the end of the 11th Five-Year Plan was in response to a "regional investment restriction" (quyu xianpi 区域限批) punishment imposed by the national government that restricted the approvals of all new energy-intensive projects for three months. To placate the national government, local leaders ordered one electricity company to cut off electricity to over 70 enterprises ${ }^{31}$ in order to have the investment restrictions lifted.

For most cases at the local level, there are fewer incentives to undertake this kind of strict enforcement, and local officials must consider local economic growth, employment, and social concerns. Major economic drawbacks of the small enterprise closures are that they decrease local GDP, tax revenue and employment numbers. Local officials partially remedy these effects by adding capacity at large, relatively efficient enterprises. Within large enterprises, approval for new production lines is normally contingent on the closure of outdated production capacity, a national policy. ${ }^{32}$ In some localities, enterprises were granted extensions while the new production facilities and equipments were under construction.

In areas with few sources of local income and no large enterprises, incentivization was more difficult and local leaders were willing to make allowances for the economic and social stability of the locality. Many local officials anticipated strong opposition to plant closure. In one reportedly isolated incident, for example, a local factory owner organized an employee protest in response to the coming closure of his enterprise. This situation resulted in the government "persuading" the owner and his employees that the closure was in the interest of the locality and that they would be provided re-employment opportunities. ${ }^{33}$

To avoid possible government-enterprise conflict, local governments take preemptive measures to decrease costs of implementation for local interests. For one small town with a single large industrial plant, the county and municipal officials allowed a small, inefficient plant to stay open because of its importance in the local economy. This was done only after making sure the plant owners

30 Guojia jingji maoyi weiyuan hui 2003.

31 China Economic Weekly 2007.

32 The national "Link small unit closures to large unit construction approvals" policy.

33 Interview 38, July 2010, municipal Economic Commission official. 
realized that they were being done a favour which they must return by making serious efforts to increase energy efficiency if they were to stay open. At the same time, local leaders emphasized that this was a temporary solution only, and that the enterprise must close eventually. In another case, a high profile closure, one local mayor brought together representatives from a number of the local departments to ensure that employees losing their jobs would be cared for by the government, and then arranged that they were provided re-employment and other forms of assistance. Some local officials also aligned their interests with those of small enterprise owners and gave enterprises the option of being able to sell or keep their equipment if they voluntarily closed ahead of the final date for closure, ${ }^{34}$ as opposed to being forced to remove and destroy equipment as set out in national policy. In this way, enterprise managers were given an incentive to implement the policy themselves, making highly visible government intervention unnecessary.

Local officials avoided conflict in the policy implementation of "elimination of backward production capacity" and small plant closure when they bundled implementation with another policy. Plant closure was implemented together with the environmental clean-up prior to the 2008 Olympics, with campaigns to improve work supervision and tax collection, and with a pollution-reduction policy. First, ESER plant closures were at times carried out in conjunction with the 2008 Olympics clean-up policy, although the link between the two policies did not become apparent to small enterprise owners until after the event. Local officials asked enterprises to close in the name of the Olympics, but were aware that national and provincial policy would allow them to prevent these enterprises from re-opening. Many small plants which had thought they would only stop production during the lead up to the Olympics and would be allowed to resume where they left off were kept from doing so by the new policies restricting energy-intensive production. ${ }^{35}$ Others were unable to reopen due to the economic climate following the global financial crisis. ${ }^{36}$

Beyond the Olympics policy-bundling, small enterprise closures were also carried out as part of a greater campaign against "low quality" small enterprise managers. The primary goals of this campaign were to improve work supervision and tax collection, yet it was loosely tied to mine closures, a policy with greater backing from high-level governments. In these cases, lack of clarity worked to the local officials' advantage, even though the plant closures were primarily ESER policy. Local officials improved regulatory capacity in local safety and tax collection, key areas for local governments, while avoiding confrontation which could count against them if any social stability concerns arose.

In addition to these methods, the prioritization of small plant closures took into account the relative pollution emitted by different industries, as all local 
officials were evaluated on $\mathrm{SO} 2$ emission reduction goals in addition to energy intensity reductions, and some localities faced pressure from provincial and, in some cases, national authorities to improve air quality. Specifically, local officials prioritized closing cement or iron and steel small plants as they benefited local officials' emissions reduction goals significantly more than other industries. Two county official interviewees stated that as long there were enough cement or iron and steel enterprises in the county that officials could close, the locality would easily meet its $\mathrm{SO} 2$ emissions reduction goals. ${ }^{37}$

Bundling of interests and policies in the closures of small coal mines was stronger than in other industries. Small coal mines have much higher rates of fatalities than large, state-owned coal enterprises ${ }^{38}$; there was increasing national media coverage of coal mine accidents in recent years; and, perhaps most importantly, beginning in 2006, the central and Shanxi provincial government renewed campaigns to force buyouts of small coal mines by large, often state-owned, enterprises as part of promoting enterprises "getting bigger and stronger" (zuo da zuo qiang 做大做强). Of more relevance to ESER policy, small coal mines have lower extraction rates than large mines, and improving the overall extraction rates in a locality counts as "saving energy" in cadre evaluations. The combinations of these factors, and in spite of the often close relations between local officials and small mine owners, brought about a shift in local officials' willingness to close small mining operations. Local officials and coal bosses saw the policy's implementation as inevitable as the national and international media coverage of mining disasters in concert with great attention from the CCP's leadership and the State Council highlighted the social and political prioritization of the policy. It was seen as only a matter of time, rather than a question of whether it would be enforced.

State-owned mining companies greatly benefit from the coal mine closure policy. National policy requires the consolidation of coal mines to the largest producers $^{39}$ and renationalization of coal resources in some regions is a top national priority. Coal SOEs are thus able to buy out a very profitable industry, one much more profitable than industrial production, at little cost and are able to regain control of energy resources, giving them and the government leverage over energy-use activities from their source. In return, they provide large bases of coal production upon which to start mine production capacity consolidation, resulting in precedents for other regions to follow.

This policy met with harsh resistance from mine bosses (meilaoban 煤老板) and other mining interests, as the government offered very low compensation for buyouts and mergers and the private owners were left with only a fraction of the value of their enterprises. ${ }^{40}$ Yet, it was still strictly enforced. After initially

37 Interview 8, June 2010, county Environmental Protection Bureau official; Interview 9, June 2010, county Economic Commission official.

38 Wang 2006.

39 National Development and Reform Commission 2007.

40 Geng 2009. 
resisting the mergers and buyouts, private coal mines began to formulate strategies to play to the interests of local governments and, in doing so, "buy time" before being forced out of the industry. These strategies focused on improving the enterprises' image of social responsibility and general benefit to society. Coal enterprises built parks and funded rural education and employment programs to position themselves with the government as "good" enterprises, and thus deserving to be among the last to undergo merger or buyout. ${ }^{41}$ This rent-seeking behaviour saw some success and some enterprises could delay scheduled plant closures. In the end, however, these enterprises knew that they could not exert enough political influence to counteract the confluence of interests aligned against them.

\section{The use of policy framing}

In both the Shanxi Top-1000 Enterprise Program and the policy of "elimination of backward production capacity" and small plant closure, officials often frame their ideas in order to play to local interests. The Top-1000 Enterprise Program and the "elimination of obsolete production capacity" and small plant closure policy are conceptualized by local officials as upgrading and production capacity restructuring programs. This framing is also used to emphasize that the ESER policies will provide social benefits in the long-run, such as more local employment opportunities and improved workplace safety.

Within this framework, the general view of local officials is that the responsibility of the Economic Commission, and the Development and Reform Commission is to shift production capacity from small or under-performing enterprises to large, efficient enterprises which can produce the greatest GDP with the lowest relative energy consumption. This conceptualization is officially based on the national policy of tying an enterprise's large project approval to its small production line closures. Yet at the local level, the policy is unofficially expanded from a shift of production capacity within a single enterprise to an inter-enterprise shift of production capacity from small enterprises, which are often closed, to large enterprises, which correspondingly expand production. Often, beneficiaries of this are state-owned or politically influential large private enterprises with access to provincial "elimination of obsolete capacity" compensation and technology-upgrade subsidies, given only to very large energy-saving projects, especially those which document savings over 10,000 tons of standard coal equivalent. Under ideal settings, local officials conceive that this shift could result in new local production greater than the eliminated capacity, higher local value-added due to greater local processing instead of exports to other provinces or municipalities for processing, and better government-enterprise relations resulting from greater tax collection. They also aim to cause little 
damage to the local economy and employment. The latter is possible even in the short term as employees of closed enterprises are generally rural migrant workers and not counted in employment statistics.

This framing is perhaps crucial to providing justification for the policies which benefit influential enterprises and individuals, especially when it seems insufficient to a local official to simply explain that large enterprises are always more efficient. They are presented as being in line with provincial policies to consolidate production capacity and increase production at the most advanced enterprises to develop "local champions," and to avoid providing assistance to small enterprises that are hard to regulate. Several local government interviewees emphasized that although many small enterprises were or will be forced to stop production, most large enterprises had created increased production capacity by the end of $2008 .{ }^{42}$ For example, according to one county-level official in charge of closures of small enterprises, the local government closed 30 small energy-intensive plants, but these closed plants each had only around one million to two million yuan total investment and around 20 to 30 employees. Although this would mean that 600-900 employees lost their jobs, the official stressed that the closure had little effect on the overall local economy. ${ }^{43}$ In another locality, one county official stated that 15 out of 37 coke plants had closed, yet large coke enterprises added more production capacity than was eliminated through plant closure policies. ${ }^{44}$ This official emphasized that although many plants had been closed, overall production capacity had increased, future profits would be greater and tax revenues would correspondingly increase, and that the locality had improved the overall "quality" of its enterprise owners by pushing small enterprise managers out of heavy industry.

\section{Conclusion}

China's energy savings and emissions reduction policies at the national level are ambitious, and they are even bolder at the provincial level in Shanxi. These efforts reflect China's national reassessment of the "growth at any cost" model and the turn towards a more sustainable, environmentally friendly, and energysecure growth path. In Shanxi, energy consumption reduction concerns have arguably been greater priorities than in other regions in China. However, the ultimate success or failure of ESER policies continues to depend on local implementation. Given entrenched interests and the many, and sometimes seemingly conflicting, demands placed upon officials, implementation of ESER policies is difficult and requires officials to find compromises with large enterprise players and to consolidate local support by forming ad-hoc coalitions.

42 Interview 31, July 2010, county Economic Commission official; Interview 36, July 2010, county Economic Commission official; Interview 44, July 2010, county economic official.

43 Interview 36, July 2010, county Economic Commission official.

44 Interview 31, July 2010, county Economic Commission official. 
Not all sub-national governments have been successful in completing ESER targets. In the months leading up to the end of the 11th Five-Year Plan, the central government increased pressure on these local governments considerably to ensure completion of the national 20 per cent energy intensity reduction target. As a last minute response, some sub-national governments undertook drastic measures to meet their energy intensity goals in ways harmful to the public interest. For example, in one county in Hebei province, the local government cut off electricity to hospitals, homes and rural villages, even to the extent that one hospital was forced to close once every four days. ${ }^{45}$ Such methods in Hebei and other regions forced NDRC to issue an emergency note in September 2010 which banned short-term electricity cuts and production limitation methods that affect residential areas and public services. ${ }^{46}$

A number of factors determine a province's ability to meet its energy intensity reduction targets, but, even under the best circumstances, local officials cannot rely only on the formal incentives and guidelines included in the national energy policies to meet targets. This research suggests that some regions such as Shanxi, for which energy consumption is especially prominent because of the high proportion of heavy industry, largely avoided a harsh, eleventh hour approach by preemptively bundling national policies with different local business and political interests. Bundling potential varies regionally given different local circumstances. In Shanxi, the many important large industrial enterprises and small competitors offer opportunities for governments to work cooperatively to protect local business interests while at the same time meeting their energy intensity targets.

In Shanxi's case, local officials bundled and built implementation capacity by strengthening formal and creating informal incentives to bring enterprise interests to improve energy efficiency on par with their own. This improved the implementation of some policies such as the Top-1000 Enterprise Program, and the "elimination of backward production capacity" and plant closure policy. This bundling and the compensatory benefits involved depended upon the communication, explanation, and assurance of formal incentives and the use of informal means such as personal appeals, persuasion, and informal promises. In so doing, government officials brought the interests of local enterprises in line with the national directives to reduce energy use. To overcome the challenges of closing energy inefficient small industrial enterprises and production lines, local implementers took into consideration the economic and employment interests of their localities to soften the landing of enforcement. Officials bundled energy efficiency policy with policies of greater local importance to ensure smooth and "harmonious" realization of energy goals, and took advantage of windows of opportunities such as the Olympics and the economic downturn to decrease the risk of protests and other forms of opposition to government intervention. Cadres' linguistic reframing of the national energy policy goals and its 
implementation provided the rationale for steps taken seemingly against the local interest. Officials used this framing to convert national energy-saving policies from a conservation-oriented and restrained development framework into local growth models aimed at creating expanded production, improving enterprise competitiveness, ensuring stable employment, and addressing growing regulatory demands at the local level.

\section{Bibliography}

China Economic Weekly. 2007. "Shanxi jieneng jianghao taotai luohou ke bu ronghuan" ("Shanxi energy conservation and consumption reduction elimination of backward [production capacity] is pressing"), 10 December 2007, available at http:/finance.sina.com.cn/china/dfjj/20071210/ 00124267955.shtml. Accessed on 16 September, 2010.

Economy, Elizabeth C. 2004. The River Runs Black: the Environmental Challenge to China's Future. Ithaca, NY: Cornell University Press.

Geng, Hua. 2009. "Shijian zai wu mei laoban?" ("Are coal bosses going to disappear from the earth?”). Nanfang zhoumo, 16 September 2009, available at http://www.infzm.com/content/34791. Accessed on 7 September 2010.

Goffman, Erving. 1974. Frame Analysis. Cambridge, MA: Harvard University Press.

Guo, Zhong. 2010. "Danghao "meitan xinzheng' shouhuzhe" ("A good guardian of the "coal new deal"”). Zhongguo caizheng bao, June 5, available at http://www.cfen.com.cn/web/cjb/2010-06/05/ content_636949.htm. Accessed on 23 September 2010.

Guojia jingji maoyi weiyuan hui (National Economic and Trade Commission). 2003. Zhongxiao qiye biaozhun zanxing guiding (Small and Medium-Sized Enterprise Standard Interim Regulation), February 2003.

International Energy Agency (IEA). 2010. "China overtakes the United States to become world's largest energy consumer," 20 July 2010, available at http://www.iea.org/index_info.asp?id=1479. Accessed 25 January 2011.

Johnson, Paul M. 2010. "Logrolling," Glossary of Political Economic Terms, http://www.auburn.edu/ johnspm/gloss/logrolling. Accessed on 6 September 2010.

Kostka, Genia and William, Hobbs. forthcoming. "Embedded interests and the managerial local state: the political economy of methanol fuel-switching in China." Journal of Contemporary China 22 (80).

Li, Xing. 2010. "Power cuts call for energy efficiency," China Daily, 10 September 2010, available at http://www.chinadaily.com.cn/bizchina/2010-09/10/content_11286604.htm, accessed on 23 September 2010.

Lieberthal, Kenneth and Michel Oksenberg. 1988. Policy-Making in China: Leaders, Structures, and Processes. Princeton, NJ: Princeton University Press.

Matland, Richard. 1995. "Synthesizing the implementation literature: the ambiguity conflict model of policy implementation." Journal of Public Administration Research and Theory 5 (2), 145-174.

Meidan, Michal, Philip Andrews-Speed, and Ma Xin. 2009. "Shaping China's energy policy: actors and processes." Journal of Contemporary China 18 (61) 591-616.

National Development and Reform Commission. 2007. 11th Five-Year Plan of Coal Industry Development, (January 2007), available at http://www.gov.cn/gzdt/2007-01/22/content_503391. htm. Accessed on September 18, 2010.

Office of the State Council. 2010. “Wen Jiabao: Luoshi zeren quebao shixian 'shiyiwu' de jieneng mubiao" ("Wen Jiabao: fulfill responsibilities to ensure realization of five-year plan energy intensity targets"), 6 May 2010, available at http://www.china.com.cn/policy/txt/2010-05/06/content_ 19978943.htm. Accessed on 18 September 2010. 
Price, Lynn, Xuejun Wang and Jiang Yun. 2010. "The challenge of reducing energy-consumption of the top-1000 largest industrial enterprises in China." Energy Policy 38 (11).

Ran, Ran. 2009. Environmental Politics at Local Levels in China: Explaining Policy Implementation Gap and Assessing the Implications. PhD Diss., University of Duisburg-Essen.

Scrase, J. Ivan. and David Ockwell. 2010. "The role of discourse and linguistic framing effects in sustaining high carbon energy policy: an accessible introduction." Energy Policy 38 (5), 2225-233.

Shanghai Zhangquan Bao. 2010. "13 dishi jieneng jianpai xingshi yanjun fagaiwei jinji tongzhi zai gao jingzhong" ("The energy savings and emissions reduction situation in 13 prefecture-level municipalities is grim: The NDRC emergency notification again sounds the alarm bell"), 8 September 2010, available at http://news.xinhuanet.com/fortune/2010-09/18/c_12582559.htm. Accessed on September 23, 2010.

Shanxi Province Bureau of Statistics. 2009. Shanxi Statistical Yearbook. Shanxi renmin chubanshe.

Shanxi sheng jingji he xinxihua weiyuanhui. 2008, 2009, 2010. Shanxi sheng jingji he xinxihua weiyuanhui tongzhi 2008. 1; 2009. 1; 2010. 2. (Shanxi Province Economic and Information Commission Notice 2008.1; 2009.1; 2010. 2).

Stern, Rachel and Kevin O'Brien. 2012. "Politics at the boundary: mixed signals and the Chinese state." Modern China 38 (2) 175-199.

van Rooij, Benjamin. 2006. "Implementation of Chinese environmental law: regular enforcement and political campaigns." Development and Change 37 (1), 57-74.

Wang, Shaoguang. 2006. "Regulating death at coalmines: changing mode of governance in China." Journal of Contemporary China 15 (46), 1-30.

Whiting, Susan. 2001. Power and Wealth in Rural China: The Political Economy of Institutional Change. Cambridge: Cambridge University Press.

Zhou, Nan, Mark Levine, and Lynn Price. 2010. "Overview of current energy efficiency policies in China." Energy Policy 38 (11), 6439-452. 